\title{
Biotechnology research in Venezuela: Five case studies
}

\author{
Rosa Morales \\ INFACES \\ Facultad de Ciencias Económicas y Sociales \\ Universidad de Carabobo \\ Av. Salvador Allende, Edif. Anexo FACES, PB \\ Valencia, 2001, Venezuela \\ Fax: 582418687378 \\ Tel: 582418687378 \\ E-mail: moralesr@uc.edu.ve
}

Financial support: Grant 326-03 from the Council of Scientific and Humanistic Development of the Universidad de Carabobo (CDCH-UC).

Keywords: human capital, Latin American biotechnology, research and development units, organization of biotechnology.

Abbreviations: BROs: Biotech research organizations
MCT: Ministry of Science and Technology
OCTI: Observatory of Science, Technology and Innovation of Venezuela

The organization of biotechnology differs across countries. The structure of the industry, the academia, and the links between these two sectors vary according to which country is studied. Biotechnology is organized in Venezuela mainly around the research done by special research and development units at national universities. The paper describes some of these units in order to shed light about their performance. Two economic approaches are used to explain the academic production of these biotech research organizations: the technological and organizational approaches. A case study methodology is used in this research. The results can be summarized as: The percentage of researchers who are doctors is less than seventy percent in each research and development unit, funding source comes basically from the Venezuelan government, strategic alliances are mainly formed between universities, performance of research and development units is mostly oriented to research but not to development . The main conclusion of this paper is that the research and development organizations are only carrying out the research function because (i) the low number of doctors, (ii) the few number of strategic alliances with the private sector and (iii) the form the research and development units finance themselves.

The organization of biotechnology presents similarities and differences across Latin-American countries. These countries have some common features related to research, development and commercialization of technology. For instance, most of the biotechnology Latin-America's research is primarily done at National Universities, and development is mainly carried out by the private sector
(Wendt and Izquierdo, 2003). Furthermore, the region's commercialization level of agricultural biotechnology has shown improvements recently (Diamante and Izquierdo, 2004). Even though there are some similarities among Latin-American countries, the structure of the industry, the academia, and the links between these two sectors vary according to which country is studied. Even countries in the same region present different characteristics in the organization of biotechnology. For example, the biotech industry of Venezuela is almost non-existent comparing with Cuba and Brazil. In fact, Brazil and Cuba show the most dynamic biotech industry of the Latin-American region (Pastor, 2004). In addition, biotech research labs in Venezuela are mostly not involved with market transaction whereas research labs from countries such as Bolivia are. Many of the biotechnology labs of Bolivian national universities are involved in market transactions related to the agricultural sector (Avila and Izquierdo, 2006). Accordingly, Venezuela may present a gap with respect to other Latin American countries at research and development level.

Research organizations in Venezuela work in different areas of biotechnology. These organizations produce basic and applied knowledge. Previous studies show that by 1997, few of them get patents on their area of research and most of them present their projects' results in journal articles and workshops (Otaiza and Arcia, 1997). This trend seems to persist in recent years. It is the purpose of this paper to describe some of the biotechnology research organizations of Venezuela in order to characterize the biotech sector in Venezuela and shed light about the causes of the performance of these organizations. This study uses different economic approaches to understand this topic.

The paper is organized as follows: First, we present the 
methodology to characterize biotechnology research organizations in Venezuela. That section states the relevant variables of this study, their dimensions and components. Second, we show an overview of the biotechnology sector in Venezuela emphasizing on the characteristics of biotech research organizations. Finally, we discuss our results and give some recommendations to improve the performance of biotechnology research organizations in Venezuela.

\section{METHODOLOGY}

We use some innovation indicators and verbal descriptions to characterize the biotech research organizations (BROs) of our study (Table 1). We collect that information through two stages. In the first one, we interview biotech experts with the purpose of knowing: (i) the general situation of the sector, (ii) which BRO still operates and where it is located, (iii) what biotech sector they work for and (iv) research line of the BROs. During the second stage we apply questionnaires to researchers and check on brochures and web pages of BROs.

In the second phase of the research, we gather information following the technological and organizational approaches. There are mainly two economic approaches to explain the production of innovation: the technological and organizational approaches. By one hand, we have the technological approach which relates human capital to the production of knowledge. On the other hand, we have the organizational approach (Dosi and Nelson, 1994; Freeman, 2002) which states the importance of networking and financing in producing innovation. Consequently, we search for information about human capital, funding, strategic allies and performance of BROs. Those variables are defined as follows:

\section{Human capital}

It is the abilities and skills of researchers (Wolff, 2001). The skills and abilities of researchers are usually related to their training and education (Filson, 2000). It is measured through the percentage of researchers who are doctors. The analysis of this variable is complemented with the characteristics and the environment of BRO given that those features impact productivity (Oliver, 2004).

\section{Funding source}

Funding is relevant for biotechnology development and so it is funding strategies (Salhevet et al. 2001). The source of funds use by researchers to finance their projects is relevant to understand their performance. We define four different sources of funding.

\section{Strategic allies}

This refers to the type of partner(s) with whom a BRO carry out their projects. The partner may be part of a network or a network itself. It also may be any organization that has programmes.

\section{Performance}

The variable shows the form in which a BRO present their production. This production can be academic or market oriented.

According to the Observatory of Science, Technology and Innovation of Venezuela (OCTI) (2004), biotechnology research organizations are scatter and there is not an easy way to account all of them. However, they count thirty four research and development organizations and 739 biotechnology researchers. Meanwhile, the CATBIO database enumerates twenty nine biotech organizations. The data from the OCTI does not allow us to distinguish between public and private research and development organizations where as we can derive that information from the CATBIO database by looking at the institution section of the database. According to CATBIO, there exist fifteen public laboratories and fourteen private research and development organizations. In our research, we count twelve public research organizations and have no information about private research and development organizations.

This study focuses on five Venezuelan biotech public research organizations that were willing to provide information about them. Venezuelan BROs perform different activities. The biotech research organizations (BROs) in our sample are linked to areas such as agribiotechnology, biomedicine, bio-informatics and genomic. BRO number one (BIOMED) is a research institute whose studies are related to the health sector with emphasis in tropical diseases. It also intends to design and optimize procedures for industry. BRO number two (CECALCULA) is part of a national program. This BRO performs research and development activities related to genetics studies both in the biology and medicine areas by using computational tools. The unit main research area is bioinformatics. BRO number three is a unit that offers genetics services related to sequencing, analysis and identification of DNA. That unit is part of a bigger national institute. BRO number four is a department of biology related to agricultural areas. It mainly performs research and teaching activities. BRO number five is an institute which research is oriented to basic and applied biology and its main study areas are cellular biology and tropical botanic. They also perform training activities. Four of the BRO in our study are part of universities; the other one is a national lab. These BROs are located in different parts of the country. Two of them are located in the capital region, one in the central area of the country, one in the western part and the last one in the Andean region of the country.

\section{RESULTS}

Venezuela as other Latin American country has developed its biotech sector mainly in the area of agriculture. The 
largest part of the Venezuelan BROs is dedicated to the agriculture sector. According to the OCTI, the percentage of research and development units working on bioagriculture reaches $59.65 \%$ of the total units, followed by the medicine sector $(19.30 \%)$. The percentage of BROs working on the area of food processing is $7.02 \%$ while the $5.26 \%$ of the research and development units is dedicated to environmental issues. The other $10.51 \%$ of the BROs work on areas such as minery, energy, oil, aquaculture, and bioinformatics. Even though the percentage of research and development units related to different areas is not uniformly distributed, the number of researchers is currently almost evenly distributed in diverse fields of biotechnology. According to the OCTI (2004), by 2003, the number of Venezuelan researchers working on the biomedicine sector reaches $24.4 \%$ of the total biotech researchers, whereas the researchers working on bio-agriculture are $21.9 \%$ of the total. In addition, the researchers' lines of study are focused in bioinformatics, genomic, fingerprints and bioethics. The last one is recently studied.

Table 1. Dimensions on which the determinants of performance are built

\begin{tabular}{|l|l|}
\hline Dimension & \multicolumn{1}{c|}{ Components } \\
\hline Human Capital & - Percentage of researchers who are doctors \\
\hline Strategic Allies & Partner: \\
& - University \\
& - Firms \\
& - State Institutes and Public Organizations \\
& - International Organizations \\
& - Network \\
\hline Funding Source & Funds from: \\
& $\begin{array}{l}\text { - Budget of National University or Public } \\
\text { - Institution }\end{array}$ \\
& $\begin{array}{l}\text { - Ministry of Science and Technology } \\
\text { - Agreements with Private Firms }\end{array}$ \\
\hline Performance & $\begin{array}{l}\text { Academic Production: } \\
\text { - Journal articles } \\
\end{array}$ \\
& - Workshop assistance \\
& - Patents \\
& Market Production: \\
& - Sales of Technology \\
& - Services to the Industry \\
\hline
\end{tabular}

The majority of biotech researchers work for BROs of national universities and very few of them work for a private company. This is consistent with the CATBIO data which shows that around $75 \%$ of the total researchers work for national universities or public laboratories. This fact is not surprising given that the biotech private sector in Venezuela is almost nonexistent and full time national universities researchers are prohibited by law to work by themselves or by other company.

Research and development units are dedicated more to research rather than development. Few of them provide products and service to certain customers (Table 2). For some researchers, the environment of the BROs does not contribute to the development of research because (a) it does not encourage inventive and creativity, (b) the organizational structure is rigid and (c) the lines of study are old fashioned. Other researchers think that the major problem of biotechnology research is the rigidity of committees in approving projects. A detailed description of the characteristics of the sample BROs is given in Table 2 .

The academic production of the BROs is mostly presented in journal articles, either national or international, and workshop assistance. We see in Table 2 that only one BRO has patents and just two have market production. As Table 2 shows, the percentage of researchers who are doctors is less than thirty five percent in three of the BROs. The percentage of researchers who are doctors and work for the other two BROs is in between fifty and seventy percent. That means that all of the BROs of our sample have less than seventy percent of their researchers with doctorate degree. This shows that the number of trained researchers is still low. This trend is similar to the tendency found in Latin America by Daza (1998) and by REDBIO reports. According to these reports, there is scarcity of human resources in Latin America that may cause technical limitations (Avila and Izquierdo, 2006). Hence, the low rate of trained researchers in the BROs of our study may be linked to the rare production of patents and to the low market performance.

On the other hand, analyzing the BROs which have more than fifty percent of doctors among their researchers, we see that one of these (CECALCULA) provides services to some enterprises and the other one (IBE) transfer technology and has patents. It seems that the higher percentage of doctors may explain why those BROs exhibit academic and market production where as the others do not. As a consequence, we conclude that trained researchers improve biotechnology development.

Other feature shown in Table 2 is that four of the total BROs have strategic allies. These allies are mostly other universities (either national or international) or state institutions. The alliances are very common among the BROs because, as it is usual in biotechnology, BROs may need other type of knowledge, techniques or information to complement and complete their projects (Gulati, 1998; Henderson et al. 1998). Examining Table 2, we see that BRO number 5 is the only one that has as allies not only universities and state institutions, but also private companies. Besides, it is the only BRO that has patents. This result is not surprising given that (a) the connection among academia and industry usually leads to the stage of development of a new product that solve needs of firms and (b) private companies have the capacity to invest enough amounts of money in developing products while the academia has the know-how. It seems that most of the Venezuelan BROs lack managerial skills to search for their allies and commercialize their research. This may be one of the causes of the BROs' low market production. That 
Table 2. Characterization of BROs.

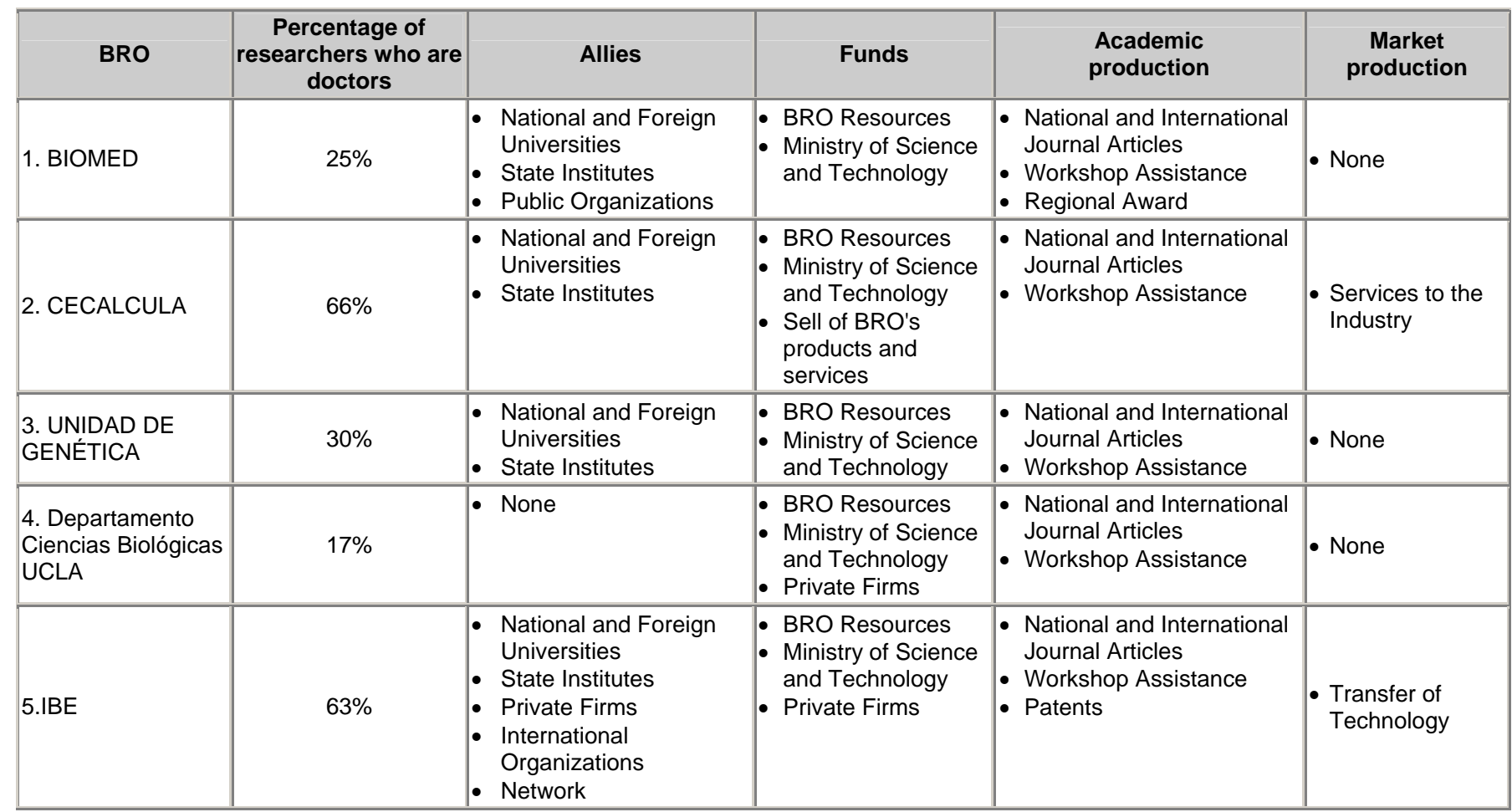

finding is consistent with Verastegui's study (Verastegui, 1999) in which he reports that the lack of innovation management skills in Latin America is one of the bottlenecks to achieve commercial biotechnology development.

The other characteristic revealed in Table 2 is that the funds through which the Venezuelan BROs finance their projects are mostly the BROs resources from national budget. These funds come basically from the part of government budget that is assigned to national universities or public institutes and transfer to BROs. These funds are used to pay researchers and they sometimes cover part of the projects' costs. Moreover, BROs use the funds of the Ministry of Science and Technology (MCT) to finance their research. Researchers have access to that type of funding through an application process. The acceptance of the application depends on the quality of the project and the alignment of the project with the priority research areas of the MCT. This sort of financing guarantees that projects are completed however is not easy to apply and approval response takes time. Other method of financing is the commercialization of tutorials and softwares. This type of funding is product of the inventive of researchers and BRO number two only uses it. The other type of funding comes from private firms and BRO number five uses this. Furthermore, BRO number five is the only one with patents and transfer of technology. Consequently, performance and source of financing may be related.

\section{DISCUSSION}

The production of biotechnology in Venezuela was focused on basic knowledge rather than applications up to the middle of the nineties (Otaiza and Arcia, 1997). The description of the five case studies shows that nowadays the production of biotechnology is still focused on publishing journal articles and presenting papers at workshops. BROs' market production is almost absent as it used to be. This study shows that only one of the BROs has patents and only two of them are related to the industry. This implies that, for the most part, the BROs are only carrying out their research function, but not the development function.

We agree with Otaiza and Arcia (1997) that: (i) scarce funding from the Venezuelan State and (ii) the type of research financed are the reasons why the development stages in the biotech industry were not reached. However, other factors, such as: (i) the low number of doctors, (ii) the few numbers of strategic alliances with the private sector and (iii) the method through which BROs finance themselves, may also explain why their production is oriented to basic knowledge rather than applied knowledge. Some Latin American countries have enhanced their biotechnology industry by linking their national universities labs with businesses and by improving their academics capabilities. Studies from CamBioTec show that Latin American countries with greater research capabilities exhibit a higher development of their biotech industry (Pastor, 2004). In addition, countries such as Bolivia have 
improved their biotech labs covering their operational expenses by linking their projects to the industry (Avila and Izquierdo, 2006). Hence, variables such as human capital, networking and funding sources not only determine the degree of development of some Venezuelan BROs but also are related to the growth of the biotech industry.

In order for the Venezuelan BROs to carry out the development part of biotechnology research and development, some policies and strategies are needed. A human capital policy is desirable at biotech level in Venezuela in order to increase the number of trained researchers. Even though the government has some funding programs to study abroad and there exist some multinational experiences to improve the number of trained people at biotech level, the number of qualified researchers in the area is still low. Therefore, the scale and scope of funding and training programs have to be broadened. In addition, a better system of incentives has to be given to trained researchers who want to come back to Venezuela and do research in their home country.

On the other hand, given that strategic alliances would facilitate knowledge and information spillovers (Audretsch and Stephan, 1999), as well as transfer of resources, BROs may have to increase strategic alliances with other organizations, either private or public, to reach the development stage. Moreover, BROs have to create strategies to search for potential allies and take care of property rights at the moment to sign agreements (Argyres and Porter, 1998). Venezuelan BROs have to improve the management of innovation given that this may speed up innovation (Terziovsky and Morgan, 2006). Even though the MCT provides support to form networks such as the REDBIO/FAO, the government may increase that help by providing databases about potential partners and by funding projects which different organizations.

Funding is other aspect that may help to improve the BROs performance. Even though, all of the BROs get funds from the MCT, there are researchers who do not apply for that financial aid. Transaction costs in applying for MCT funding and the time it takes to receive funds discourage researchers to get funds from this source. Long application forms and timeless response has to be modified to facilitate applications and timely financing. The scale of governmental funds also has to be broadened and monitored. Conversely, BROs may search for private funding to develop and commercialize products.

\section{ACKNOWLEDGMENTS}

The author thanks Dr Jose Luis Ramirez and Dr Diógenes Infante for giving overall information about biotech research in Venezuela. In addition, she acknowledges the collaboration of the studied BROs. Finally, the author thanks two anonymous referees for comments.

\section{REFERENCES}

ARGYRES, Nicholas S. and PORTER LIEBESKIND, Julia. Privatizing the intellectual commons: Universities and the commercialization of biotechnology. Journal of Economic Behavior and Organizations, May 1998, vol. 35, no. 4, p. 427-454.

AUDRETSCH, David B. and STEPHAN, Paula E. Knowledge spillovers in biotechnology: sources and incentives. Journal of Evolutionary Economics, February 1999, vol. 9, no. 1, p. 97-107.

AVILA, Teresa and IZQUIERDO, Juan. Management of appropriate agricultural biotechnology for small producers: case study - Bolivia. Electronic Journal of Biotechnology [online]. 15 January 2006, vol. 9, no. 1 [cited 13 February 2006]. Available from Internet: http://www.ejbiotechnology.info/content/vol9/issue1/full/4/ index.html. ISSN 0717-3458.

DAZA, Camilo. Scientific research and training in biotechnology in Latin American and the Caribbean: the UNU/BIOLAC experience. Electronic Journal of Biotechnology [online]. 15 August 1998, vol. 1, no. 2 [cited 21 March 2004]. Available from Internet: http://www.ejbiotechnology.info/content/vol1/issue2/full/5/ index.html. ISSN 0717-3458.

DIAMANTE, Alicia and IZQUIERDO, Juan. Manejo y gestión de la Biotecnología Agrícola apropiada para pequeños productores: estudio de caso Argentina. April. REDBIO/FAO [online]. April 2004, 76 p. [cited 15 October 2005]. Available from Internet: http://www.redbio.org/documentos/manejo_y_gestion.doc.

DOSI, Giovanni and NELSON, Richard R. An introduction to evolutionary theory in economics. Journal of Evolutionary Economics, September 1994, vol. 4, no. 3, p. 153-172.

FILSON, Darren. The dynamics of resource allocation in research organizations. Journal of Economic Behavior and Organizations, October 2000, vol. 43, no. 2, p. 263-277.

FREEMAN, Chris. Continental, national and sub-national innovation system-complementarity and economic growth. Research Policy, February 2002, vol. 31, no. 2, p. 191-211.

GULATI, Ranjay. Alliances and Networks. Strategic Management Journal, April 1998, vol. 19, no. 4, p. 293317.

HENDERSON, Rebecca; ORSENIGO, Luigi and PISANO, Gary P. The pharmaceutical industry and the revolution in molecular biology: interactions among scientific, institutional, and organizational change. In: MOWERY, David C. and NELSON, Richard R. eds. Sources of Industrial Leadership: Studies of Seven Industries. 
Cambridge, Cambridge University Press, 1998, p. 267-311.

Observatorio Nacional de Ciencia, Tecnología e Innovación (OCTI). Número de investigadores en Biotecnología por categorías y especialidades en Venezuela 2003. Boletín "Entre Nosotros": Reporte Estadístico No 11, 2004, 2 p. [cited 12 January 2005]. Available from Internet: http://www.octi.gov.ve/documentos/archivos/103/Entre_No s_11.pdf.

OLIVER, Amalya L. Biotechnology entrepreneurial scientists and their collaborations. Research Policy, May 2004, vol. 33, no. 4, p. 583-597.

OTAIZA-VÁSQUEZ, Edgar and ARCIA, Asdrubal. Plant Biotechnology in Venezuela: A Myth? A critical evaluation to determine ITS Status and Social Impact. Interciencia, September 1997, vol. 22, no. 5, p. 238-246.

PASTOR SOPLIN, Santiago. Manejo de la Biotecnología apropiada para pequeños productores: estudio de caso-Perú. REDBIO/FAO, November 2004, 62 p. [cited 10 October 2005]. Available from Internet: http://www.redbio.org/e_casos/Adjunto_Peru.pdf.

SALHEVET, Sarit; HARUVY, Nava and SPHARIM, Ishai. Management strategies for agricultural biotechnology in small countries - A case study of Israel. Biotechnology Advances, November 2001, vol. 19, no. 7, p. 539-554.

TERZIOVSKY, Milé and MORGAN, John P. Management practices and strategies to accelerate the innovation cycle in the biotechnology industry. Technovation, May-June 2006, vol. 26, no. 5-6, p. 545-552.

VERÁSTEGUI, Javier. Transferring expertise and building capacities in Agri-Biotechnology: the experience of CamBioTec. Biotechnology and Development Monitor, September 1999, no. 39, p. 2-7. [cited 18 November 2003]. Available from Internet: http://www.biotechmonitor.nl/3902.htm.

WENDT, Jan and IZQUIERDO, Juan. Management of appropriate agricultural biotechnology for small producers: case study - Ecuador. Electronic Journal of Biotechnology [online]. 15 April 2003, vol. 6, no. 1 [cited 16 October 2005]. Available from Internet: http://www.ejbiotechnology.info/content/vol6/issue1/issues /02/. ISSN 0717-3458.

WOLFF, Edward N. The role of education in the postwar productivity convergence among OECD countries. Industrial and Corporate Change, August 2001, vol. 10, no. 3, p. 735-759. 